\title{
真性赤血球増加症と続発性痛風
}

\author{
東京大学医学部内科物理潦法学教室（主任 大島良雄教授） \\ 赤岡 家雄 西沢常男菊谷 豊彦 \\ 吉村隆村中 正治
}

\section{POLYCYTHEMIA VERA AND SECONDARY GOUT}

Ieo Akaoka, Tsuneo Nishizawa, Toyohiko Kikutani,

Takashi Yoshimura and Masaharu Muranaka

Department of Physical Therapy and Medicine, Faculty of Medicine, University of Tokyo

(Director: Prof. Yoshio Oshima)

\begin{abstract}
概要 真性赤血球增加症と，高尿酸血症ないし痛風症との合併は，欧米ではまれなものではないが， 本邦では1961年著者らの発表が，第 1 例である. 本症例につき 6 年間にわたる経過を，血清尿酸值， 尿中尿酸排泄，尿酸クリアランスなどの尿酸代謝化重点をおいて観察した。また，本例を含み最近経 験した 7 例の赤血球增加症例の尿酸代謝を検討した． 7 例中 5 例では高永酸血症を認め，この 5 例中 4 例は痛風であつた， 2 例の真性赤血球增加症に合併せる痛風例は，尿酸排泄增加之著明な高尿酸血 症を示した. 真性赤血球増加症に括ける尿酸代謝異常の発現機序にかんし, 核酸の過剩崩罣の問題, 本症の造血采細胞の形態学的問題，いわゆる“stem cell”なる概念との関連などについて，最近の文 献る引用して考察した。 また，尿酸の過剩排泄が原因すると考㐫られる尿路結石症や二次的腎障害な ぞが，本症の成立進展に演ずる役割についてる検討した。
\end{abstract}

\section{緒言}

原発性痛風は近年本邦でもしばしばみられる疾 患であるが，真性赤血球増加症に合併した続発性 痛風症はきわめてまれで, 昭和36年リウマチ談話

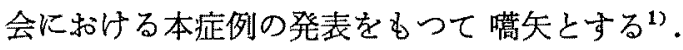
われわれは，初診後 6 年間にわたり，尿酸代謝を 中心に本症例の経過を観察したので報告する。 た，赤血球増加症の尿酸代謝について臨床的検討 を行ない，若干の文献的考察を加えた。

症例

患者. 62 才, 男子, 建築業.

本症例は昭和36年第 6 回りウマ談話会拉よび昭 和 40 年第 5 回日本臨床血液学会に扰いて報告した もので，本諭交はさらにそれに追加検討を加えた わのである。
主訴：右足関節，両側第 1 中足趾関節などの 急性関節炎発作.

家族歴：父は60才で急性心疾患，母は85才老 衰で死亡．姪が36才で関節リウマチに罹患してい る汪かは，特記すべきものはない。

既往歴： 分婏正常. 37 才より 2 年間兵役で 南方に派遣されたほか，東京を離れたことはな い.15才より大工として後述の関節炎発作を文る までは労務に従事していた．26才で急性虫垂炎手 術. 38才戦地でデング熱に羅患. 食事は肉食を好 み，酒は和もに日本酒 2 合，凐草は12本程度。

現病歴： 昭和 27 年。右第 1 趾関節部を挫 し，軽度腫脹と運動障害を伴なつたが，一般的治 療で軽快治癒した。昭和 29 年ごろ患者が50才のと 
き，他人より顔面潮紅を指摘されたが，自覚的苦 痛はなかつた．昭和31年ごろから起立性めまいと 飛蚊症を自覚するようになつたが，医療は受けて いない

昭和 33 年 2 月（54才）なんらの誘因なく左第 1 中足趾関節部の疼痛, 発赤, 腫脹が出現し, 約 1 週間で自然に軽快した。 その後， 1 年に $3 \sim 4$ 回 該部に同様な発赤疼痛性腫脹発作を繰り返してい る.諸医家を訪れているが，多くの場合，関節り ウマチの診断で鎮痛下熱薬の内服，注射，局所の 冷罨法等を受けたり，ときには膿湟として切開手 術を受けたこともある。しかし関節症状の持続は 每回約 1 ～週で，治療法の差異にあまり関係し ない，症状軽快とともに局所の落屑をみる．無症 状期にはとくに趾先に力を入れなければ普通に労 働しえた。関節症状のほか昭和33年ごろ数日間， 尿が赤色（血尿？）になつたことがあり。すた昭 和35年には露視を 3 日間経験している。昭和 35 年 9 月, 両側第 1 括よび右第 2 中趾関節に急性関節 炎発作があり，某病院で慢性関節リウマチではな いといわれたが，診断は明らかにされなかつた。 最近では昭和 36 年 2 月に右足関節，6月に左第 1 趾と右膝関節部の疼痛性腫脹発作, また 9 月に右 前腕部の神経痛様疼痛など症状が多彩となつてき た. 昭和36年10月11日当科外来に受診し，高尿酸 血症，X線像，末梢血液所見などから赤血球增加 症に併発した続発性痛風として入院.

現病歷から推定される発病年令は，赤血球增加 症50才 (昭和 29 年), 痛風が54才（昭和33年）とな る。

現症：体格栄養は中等度, 身長 $168 \mathrm{~cm}$, 体重 $56 \mathrm{~kg}$, 意識言語に異常なし. 体温正常, 脈拍 78 , 整調, 緊張良, 撓骨動脈渾度の硬化がある。血 臣 132/88.

顔面，手背部は暗赤色を呈し(Red cyanosis)， 一部に斑点状色素沈着を認める。眼球結膜は充血 し, 眼䀫結膜は深紅色, 角膜に混浊がある. 瞳孔 に異常なく，眼底は全体が暗赤色調で静脈の怒張 がある。視野正常, 視力は右 0.8 ，左 1.0 であ る. 口唇は暗赤色, 口腔粘膜は紫紅色. 舌は軽度
の白色舌苔で被われている、リンパ節の異常庫脹 を認めない。

胸部の吒打痛，王痛はない 肺肝境界は第 5 肋 間腔でやや上昇し，肺野の理学的所見は正常，心 浊音界は左が乳線上り 2 横指左方に拡大，心音は 心尖部で軽度の収縮期性雑音と, 第 2 肺動脈音の 六進があるが，心基部心音は純である。

腹部は平坦，静脈怒張なし、肝臓腫大は明らか でない，脾臓は $(13.6 \times 24.7 \mathrm{~cm})$ 腫大し，硬度増 加, 平滑.

四肢では両側第 1，2 趾を除いて運動, 知覚, 反射機能に異常なし.両側第 1 中足趾関節部に硬 い暗赤色腫脹あり，局所熱はないが圧痛を認め， 運動制限もある. 左第 2 中足趾関節にも圧痛があ る。

\section{臨床検查成續}

1）尿；淡黄褐色, 透明, 酸性, 蛋白 $(H)$, 糖 (-), Urobilinogen ( + ), Urobilin (-), 沈渣 では赤血球 $2 \sim 3$ 個，白血球特よび上皮細胞は， 毎視野 $1 \sim 2$ 個，蛋白定量 $1 \%$.

2) 便; 潜血反応Benzidine(十), 虫卵(一), Urobilinogen $222 \mathrm{mg} / 100 \mathrm{~g}$.

3） \%反応；(十).

4）血清反応；Wassermann反応 (-), Coombs 試験（一),リウマチ反応はRose，Latex F.とも陰 性, A S L O (一).

5）赤沈； 1 時間， 2 時間とも $0 \mathrm{~mm}, \mathrm{C} \mathrm{R} \mathrm{P}$ $(-)$.

6）血夜生化学; 総蛋白量 $8.4 \mathrm{~g} / \mathrm{dl}, \mathrm{A} / \mathrm{G}$ 0.96 ，蛋白分画は, $\mathrm{Al} 36.1, \alpha_{1} 3.7, \alpha_{2} 9.0, \beta$ $16.7 \uparrow, \gamma 36.6 \uparrow$, 尿素-N15.5mg/dl, 電解質 $\mathrm{Na} 141$ $\mathrm{mEq} / l, \mathrm{~K} 5.8 \mathrm{mEq} / l, \mathrm{Cl} 103 \mathrm{mEq} / l$, 血清鉄 $110 \gamma / \mathrm{dl}$, Acid-P-ase 1.0 単位.

7）肝機能検査；黄疸指数 6 , 総Bilirubin 0.4 $\mathrm{mg} / \mathrm{dl}$ (直接 0.2 , 間接 0.2 ). T T T 5.0, Z T T 14.0, alk-P-ase $6.9 \uparrow$. B S P 10\% (45分).

8）腎機能検査; ' Fishberg濃縮試験1,042, P S P 10\% (15分)，48\%（2時間)，G F R 102.5 $\mathrm{ml} / \mathrm{min}, \mathrm{RBF} 1,344 \mathrm{ml} / \mathrm{min}, \mathrm{RPF} 419 \mathrm{ml} / \mathrm{min}, \mathrm{FF}$ 
0. 25 .

9） X線検查； 胸部 $X$ 線の肺野では右横隔膜 やや高位, 血管影増強，心影で左室肥大と大動脈 弓の延長を認める。

四肢骨では両足のみに異常を認める（図 1 ， 2 ). 左第 1 趾の中足骨遠位外側縁に鋸歯状 の 骨 破壊，基節骨下端に軽度の増殖性変化として骨縁 堤 (Randwulst) があり，左右第 1 趾中足骨基節 骨の皮質萎縮を認める.中足趾関節面の不整, 関 節腔の狭少はない。

消化管X線像では脾腫による胃腸の圧迫像があ るほか，潰瘍，炎症像はない。

泌尿器系では尿路結石および腎盂輸尿管の異常

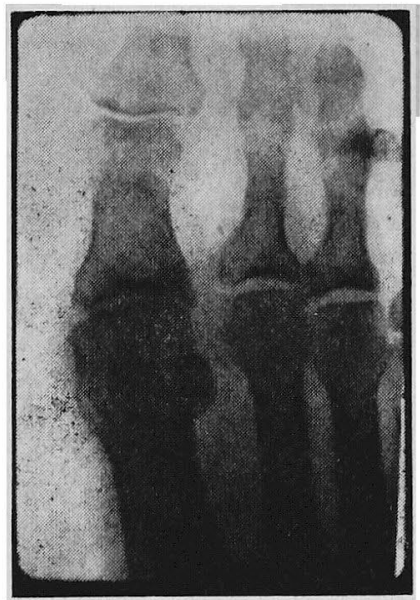

図 1

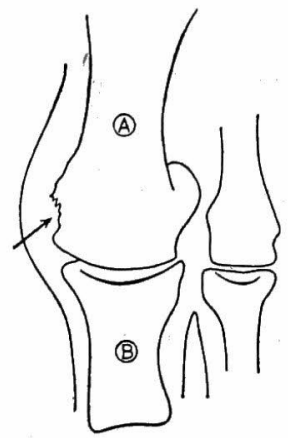

A 左第 1 中足骨

B 左第 1 基節骨 々印部鋸眥状骨破壊像

図 2
を認めず。

10）血液学的検査（表 1); 末梢血では, 赤血 球 $980 \times 10^{4}$, 血色素量 $21.4 \mathrm{~g} / \mathrm{dl}$, 色素指数 0.67 , Ht $71 \%$, 白血球 16,200 , 血小板 $63.8 \times 10^{4}$, 網状 赤血球 $12 \%$ で，三有形成分とも増加している。

骨髄像 (胸骨穿刺) では 有核細胞 $37.6 \times 10^{4}$, 巨核球 496で骨髅機能の立進があり，M/E 3.6で ある。

出血性素因では，出血時間 3 分，凝固時間 7 分 30秒, Rumpel-Leede (一), prothrombin 時間20.7 秒, 血餅収縮能正常. thromboelastogramm 正常, 赤血球平均直径 $7.1 \mu$, 平均赤血球容積 $72.5 \mu^{8}$, 赤血球抵抗はmin. $0.50 \%, \max .0 .34 \%$ である。 血液粘稠度 8.10 , 血舀粘稠度 1.77 , 血液比重 1.070 , 血浆比重 1,026 , 循環時間 (腕〜舌) 27.5 秒, 循環血液量 $10,300 \mathrm{ml}(187.2 \mathrm{ml} / \mathrm{kg})$, 循環血 球量 $7,370 \mathrm{ml}(133.9 \mathrm{ml} / \mathrm{kg})$, 循環血浆量 2,930 $\mathrm{ml}(53.3 \mathrm{ml} / \mathrm{kg})$. 白血球のalkaline phosphatase活 性は, 陽性率 100 , 陽性指数 562 で高値である.

11）尿酸代謝； 初診時の血清尿酸值 $14.4 \mathrm{mg} / \mathrm{dl}$,

表 1 . 血液学的検查

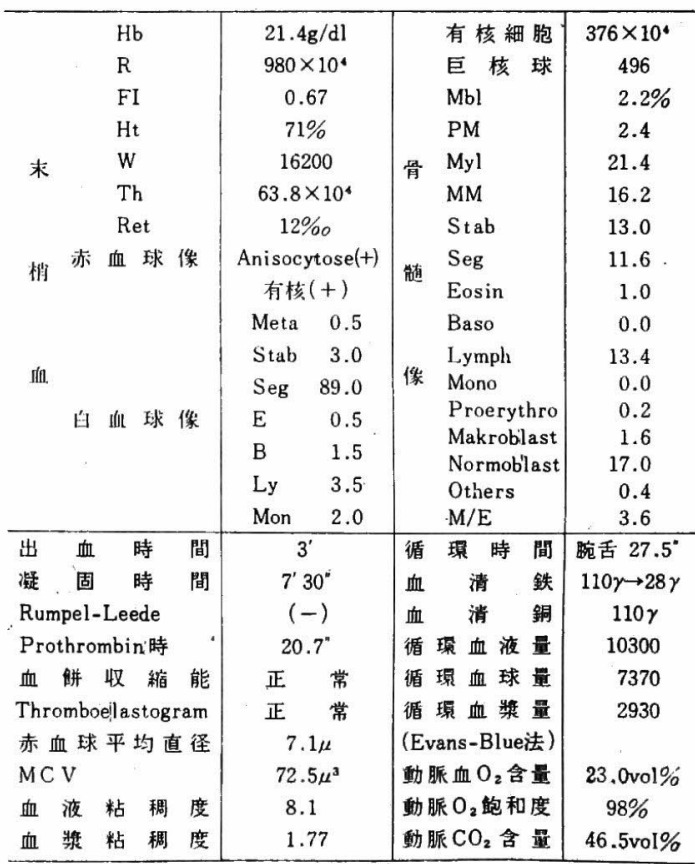


入院時は $10.8 \mathrm{mg} / \mathrm{dl} て ゙$ 高值. 食事を入院患者の普通 食とし（平均蛋白質 $77 \mathrm{~g}$, 糖質 $374 \mathrm{~g}$, 脂肪 45 $\mathrm{g}$ ，総カロリー2,218Cal)，7 日間の平均尿量 $2,250 \mathrm{ml} / \mathrm{day}$, 尿酸排泄量 $915 \mathrm{mg} / \mathrm{day}$ で増加して いる，尿酸クリアランスは $7.4 \mathrm{ml} / \mathrm{min}$ で正常.

12）その他の諸検查；BMR+23\%，心電図で 左室肥大と高位前側壁の障害を認める. 動脈血ガ ス分析では, $\mathrm{CO}_{2} 46.5 \mathrm{vol} \%, \mathrm{O}_{2} 23.0 \mathrm{vol} \%, \mathrm{O}_{2}$ 飽 和度98\%。指および趾のplethysmographyの波形 正常.

診断： 本例の診断根拠の詳紐は，既に報告し たので省略する゙2 すなわち, 赤血球の増加, $\mathrm{Ht}$ の増加に伴なつて, 白血球, 血小板も増加してい る点, 著明な循環血液量, 循環血球量の增加, 骨 髄造血能の亢進, 白血球alkaline phosphatase活性 の増加，著明な肺心疾患がないなどの所自から， 真性赤血球增加症と訅断される。一方，特街的な 急性関節炎発作，高尿酸血症，後述のごとさ右第 4 指に括けるTophus, desacetylmethylcolchicine による関節発作の完全緩解などから，痛風症と診 断される。また痛風症発現の約 4 年前に顔面の潮 紅すなわち赤血球増加症が存在したことが確から しいので真性赤血球增加症に続発した二次性痛風 症と診断した。

程過および治療： 入院中, およびその後の 6
年間にわたる赤血球增加症および痛䖝症の治療経 過は，図 $3 ， 4$ 亿示寸ごとくである.痛風発作時

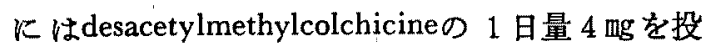
与することにより $3 〜 4$ 日後に疼痛は緩解した. その間, 血清尿酸值は $10 \mathrm{mg} / \mathrm{d} 1$ 程度で著変はなかつ た.ついで尿酸排泄薬としてprobenecid $1.0 \mathrm{~g} /$ 日， sulfinpyrazone $0.4 \mathrm{~g} /$ 日, zoxazolamine $0.8 \mathrm{~g} /$ 日 などの投与により血清尿酸值は $7.2 \sim 3.9 \mathrm{mg} / \mathrm{dl}$ に 低下し，尿中尿酸排泄量は約 $1,500 \mathrm{mg} /$ dayk増 加した，血色素，赤血球数がやや低下している。 その後, ${ }^{32} \mathrm{P}$ の $3.1 \mathrm{mC}$ を静注, さらに2 月後 4.4

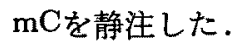

初診より 2 年後, 血色素 $18.4 \mathrm{~g} / \mathrm{dl}$, 赤血球 954 $\times 10^{4}$ ，色素指数 $0.60, \mathrm{Ht} 59 \%$ ，低色素性は増 強し, 白血球 50,000 , 血小板 $93 \times 10^{4}$ と増加し, 骨 䯣では有核細胞 $8.5 \times 10^{4}$ ，巨核球 $16, \mathrm{M} / \mathrm{E}$ 比 3.0 となつた，血清鉄は28 $\gamma$ と低值，不飽和鉄結合能

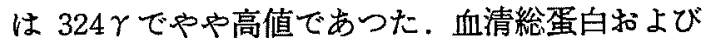
蛋白分画はあまり変化をみなかつた．痛風の治療 は放置していたため，関節発作頻度は年 $3 \sim 5$ 回 で変らなかつた．血清尿酸値は $6.1 \mathrm{mg} / \mathrm{dl} て ゙$ 低值を 示したが，尿酸クリアランスは $5.7 \mathrm{ml} / \mathrm{minで，以}$ 前より低下, creatinineクリアランスは65.0 $\mathrm{ml} / \mathrm{min}$ で，GFRがやや低下した。

初診 4 年後, 食欲不振を訴光, 黄疸指数は12で

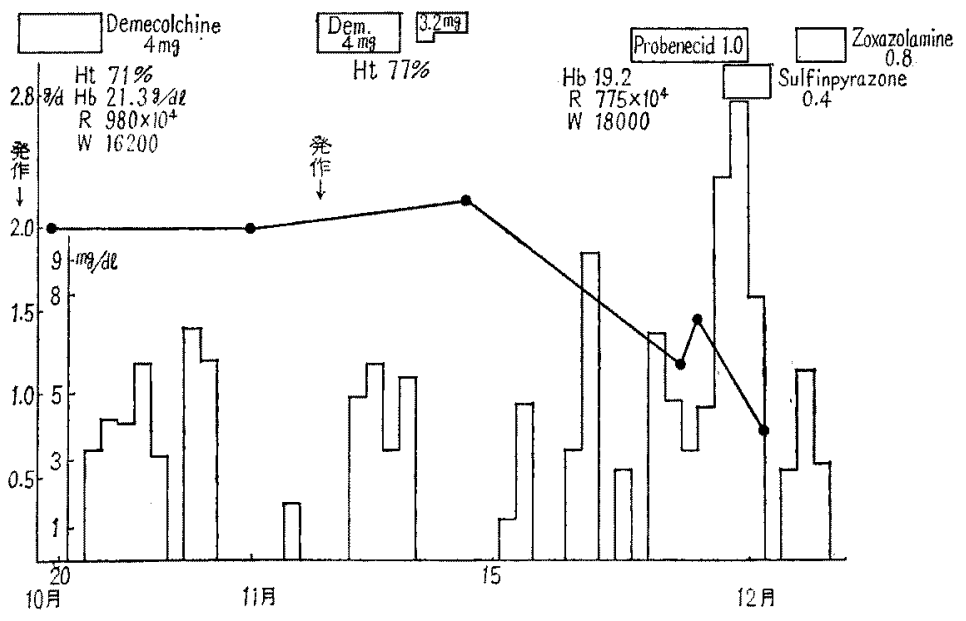

図3，入院時释過出○浅○郎62才，男。 


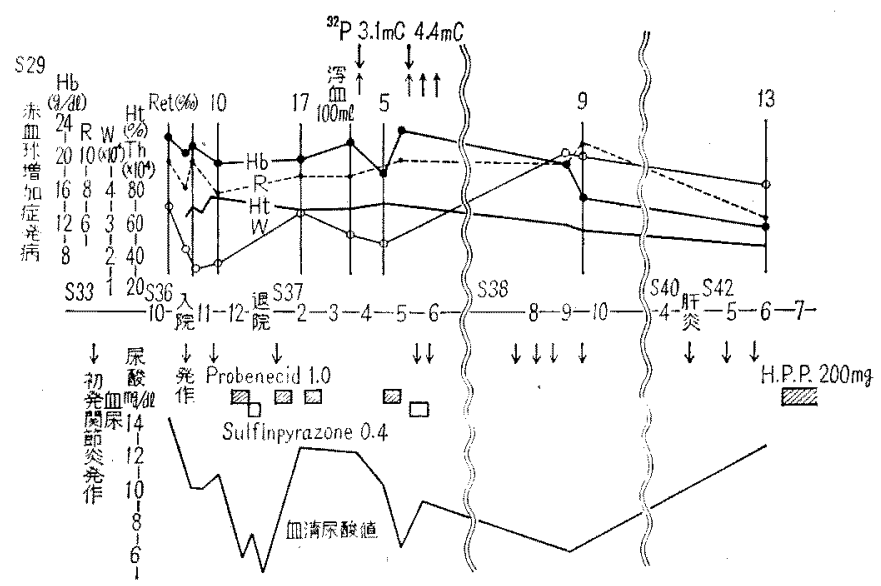

図 4. 全経過图 ○口○太○62才，男。

あつたが，GOT 354，G P T 222で急性肝炎を 併発した。

初診 6 年後, 顔色はすでに正常で，脾腫はほぼ 不変, 肝腫が認められるようになつた。血色素 $11.2 \mathrm{~g} / \mathrm{dl}$, 赤血球 $618 \times 10^{4}$, 色素指数 $0.70, \mathrm{Ht}$ $45 \%$, 網赤血球 $13 \%$ ，赤血球不同症，奇型赤血球， 多染性赤血球があつた。白血球は40,900, 肝機能 としてGOT，GPTは正常に戻つていた．痛風 にかんしては，右第 4 指に痛風結節を形成し，血 清尿酸值は $12.4 \mathrm{mg} / \mathrm{dl}$ で再び高值となつた。痛風 の治療としては，尿酸排泄薬に代觉て，xanthine oxidase活性抑制薬で尿酸生成を阻害する H P P を投与開始し，現在に至つた。

赤血球増加症における高尿酸血症

対象扣よび方法：赤血球増加症の基準として
Damonらの赤血球 630 万，血色素 $18 \mathrm{~g} / \mathrm{dl} ， \mathrm{Ht} 55$ $\%$ 以上をとつだ．当科に执いて最近経験せる7 例（表 2 ）の赤血球増加症は, 全例男子, 年令は 28才から63才まで.7例の血色素は 17.7〜31.4 $\mathrm{g} / \mathrm{dl}$, 赤血球 548 万〜 1,002 万, 色素指数は 0.67 $\sim 1.24, \mathrm{Ht}$ 法 $53 \sim 85 \%$, 白血球 $6,500 \sim 18,500$, 血小板 9.6 万〜 63.8万.1)2)は三有形成分のいず れも増加し，2)ではerythropoietin活性正常であ る. 白血球alkaline phosphatase活性は，1)で陽性 率100(正常値83土6), 陽性指数 562 (正常值 288 土51），2)ではそれぞれ100および 502で増加して いる。症例別にみると，1)2)の 2 例はいずれも痛 風発症の 4 年前すでに赤血球增加症の存在が推定 されており，Vaquez型のpolycythemia rubra vera に二次性痛風症が発現したものである，1)は本報

表 2 ．赤血球增加症 7 例の尿酸伦謝

\begin{tabular}{|c|c|c|c|c|c|c|c|c|c|c|c|c|c|c|c|c|c|c|c|c|c|}
\hline \multirow{2}{*}{ 唗 } & \multirow{2}{*}{ 综合 } & \multirow{2}{*}{ 啃: } & \multirow{2}{*}{ 笔狱年会 } & \multirow{2}{*}{$\begin{array}{c}H \mathrm{~b} \\
(\mathrm{~g} / \mathrm{d} 1)\end{array}$} & \multirow{2}{*}{$\left.\mid \begin{array}{c}\mathrm{R} \\
\left(x 10^{4}\right.\end{array}\right)$} & \multirow[t]{2}{*}{$\mathrm{FI}$} & \multirow{2}{*}{$\begin{array}{l}\text { Ht } \\
(\%)\end{array}$} & \multirow[t]{2}{*}{ W } & \multirow{2}{*}{$\left|\begin{array}{c}\mathrm{Th} \\
\left(x ; 0^{*}\right)\end{array}\right|$} & \multirow{2}{*}{$\begin{array}{c}\text { Ret } \\
(\%)\end{array}$} & \multicolumn{2}{|c|}{$\begin{array}{c}\text { G for alkal ine } \\
\text { phosphatase }\end{array}$} & \multirow{2}{*}{ Eryhtoposetin } & \multicolumn{3}{|c|}{ 县 } & \multirow{2}{*}{ 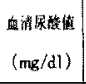 } & \multirow{2}{*}{ 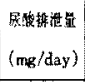 } & \multirow{2}{*}{ 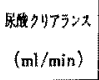 } & \multirow{2}{*}{$\left|\begin{array}{c}\text { GFR } \\
(\mathrm{m} / / \min )\end{array}\right|$} & \multirow{2}{*}{$\begin{array}{c}\mathrm{RPF} \\
(\mathrm{m} / \mathrm{min})\end{array}$} \\
\hline & & & & & & & & & & & 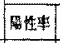 & 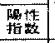 & & $M / t$ & 有 极 & 巨校蚌 & & & & & \\
\hline GOMOkO & 62 & s. & $\begin{array}{l}50 \text { Polycylhemia } \\
54 \text { Gout }\end{array}$ & 91.4 & 980 & 0.67 & 71 & 16200 & 63.8 & 12 & 100 & 562 & & 3.6 & $37.6 \times 10^{4}$ & 496 & 10.8 & 915 & 7.4 & 103 & 420 \\
\hline 20 消O之O & 60 & 今 & $\begin{array}{l}55 \text { Polycyltemia } \\
59 \text { Gouth }\end{array}$ & 22.9 & 651 & 1.10 & 66 & 18500 & 35.8 & 21 & 100 & 502 & 㱐 & 2.8 & $15.3 \times 10^{4}$ & 96 & 11.0 & 726 & 7.6 & 73 & 338 \\
\hline (3) & 28 & $\$$ & 18 Gout & 18.7 & 628 & 0.93 & 53 & 8900 & $4 \mathrm{I}, 6$ & 8 & 90 & 183 & E & 2.6 & $16.1 \times 10^{4}$ & & 11.8 & 618 & 3.1 & 97 & 187 \\
\hline (4) 龱 0 留 & 63 & d & $\begin{array}{l}53 \text { Polycythem: } \\
62 \text { Gout }\end{array}$ & 17.7 & 575 & 0.96 & 55.5 & 6500 & 17.5 & 8 & & & & & & & 6.9 & & & & \\
\hline 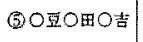 & 38 & 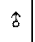 & 33 Polycythemia & 29.1 & 1002 & 0.91 & 82.5 & 7500 & 9.6 & 18 & & & 正 桬? & 4.4 & $19.0 \times 10^{4}$ & 48 & 7.7 & 600 & & & \\
\hline $60 月 0 \mathrm{kO}$ & 55 & $d$ & $?$ & 31.4 & 813 & 1.20 & 85 & 17300 & 53.6 & 8 & & & 王 散 & 2.3 & $10.0 \times 10^{4}$ & 80 & 4.8 & 750 & & & \\
\hline (1) 0 变 0 & 55 & $\sqrt{b}$ & $?$ & 21.7 & 548 & $1: 24$ & 65 & 7300 & 12.6 & 2 & 76 & 256 & & & $2.5 \times 10^{4}$ & 2 & 5.8 & & & & \\
\hline
\end{tabular}


告例で，2)は第184回内科学会関東地方会で荒田 らがすでに報告した症例である．3)4）の 2 例は痛 風の診断をうけて後，赤血球増加症を合併してい ることが判明した例である.症例3)〜7)の 5 例は 症候性赤血球增加症と考光られる。

血清尿酸值は 7 例全例，尿中尿酸排泄量は 5 例，尿酸クリアランスは 3 例で測定された．

成績：血清尿酸值は，痛風を合併した1) 4) 例のはか5)例も高值で11.8〜6.9m//dlである。す なわら 7 例中 5 例 $(71 \%)$ が高疗酸血症，之例は ほぼ正常值とみられる。7例中 4 例，(57\%）が 関節资発作をるち，痛風症を合併している，尿中 尿酸排泄量を測定したものは5例で，600〜915 $\mathrm{mg} / \mathrm{day}$ と、いずれるかなり排泄量が多い 尿酸ク リアランスは1)2)で 7.4〜 7.6ml/min と正常，3) のみ 3.1 $\mathrm{ml} / \mathrm{min}$ で低下している. G F R，R P F は3 例でほぼ正常ないし，やや低下している。

\section{考案}

血液疾患のうち，いわゆる「続発性痛風症」を 来たすことが多い疾患として，真性赤血球増加症

(以下 $P \vee$ と略す), 二次性赤血球増加症，白血 病，骨䯣化生，悪性貧血などがある。これらの疾 患の大多数の患者では, 痛風症は原疾患に扣くれ て顕性となるが，時に急性関節炎が初発症状であ つたり，血清尿酸値上昇が血液疾患の最初の所見 であつたりすることむある゙)

ここでは主としてPVに続発せる二次性痛風症 の発生頻度，診断之予後，扣よび赤血球増加症之 高尿酸血症の関係について検討し, 二次性赤血球 増加症についても簡単にられることとする。

発生頻度： 欧米ではPVに合併せる続発性痛 風は古くから知られ，最近ではかなり多症例を骤 めた報告がある5 つど) つと1923年Isaacsにより， 赤血球増加症では，しばしば高尿酸血症と尿酸排 泄増加がみられることが示された。つでKinell らは, 痛風症の $24 \%$ は赤血球 500 万以上で, 6 \%は血色素 $100 \%$ 以上であると報告している9 GutmanらはP V に高尿酸血症を合併する頻度之 して約 $1 / 3^{5)}$. Stroebel は28\% ${ }^{10)}$. Denmanらは55
\%を経験している7

さらにPVに二次性痛風の合僧する頻度とし て，Videbeckは 125例中11例 $(8.8 \%)^{112}$, Laurenceらは 269例中21例 $(7.8 \%)^{12)}$, Damonは 197 例中11例 $(5.6 \%)$ をえている18) Stroebelは 142例の P Vを末梢白血球像か５，1) simple，2） mature leucocytic，3)leukemoid 33 形に区分し, 痛風の頻度については，1)で 8\%，2)で15\%，3） で46\%と，幼若白血球型のP V V高頻度の痛風発 症が認められると報告した ${ }^{10)}$ 最近, Denmanら は18.7\%の高頻度を報告している ${ }^{8)}$. 結局，欧米 ではPVの6〜19\%に痛風の発症が経験されてい ることになる。

本邦では近年, 原発性痛風症はかなり多い疾患 であるが，PVは日比野教授によれば，明治 42 年 （1909）から昭和35年（1959）の50年間に 134例 がみられたのであると報告されている14) そのら ちで，既往歴に「ロイマチスム」のあるすのが90 例中 2 例 $2.2 \%$, 主訴括よび初発症状として四肢 疼痛を訴えたもの5\%をみるが，これが果して続 発性痛風の関節炎であつたか否かは明らかでな W.

二次性赤血球増加症は，PVについで続発性痛 風を合侀する頻度が高い二次性赤血球増加症の 原因疾患としては，肺機能不全，先天性心疾患 を主とする心不全，腎腫場などがあげられる。 Somervilleは先天性心疾患による二次性痛風 9 例 を報告し，これには腎機能不全も関与していると のベている ${ }^{15)}$ Lewisは慢性肺疾患で血色素 120 $\%$ 以上の90例中 7 例に痛風の発生をみた ${ }^{16)}$ また Damonは腎蔵癌に続発した赤血球増加症で, 痛風 の発病をみたもの10例を綑めて 報告している

診断と予後：骨䯣増生に伴な5続発性痛風 （主としてPVに伴なら続発性痛風）と原発性痛風 とでは，多少異なつた臨床的特徽がみられる。両者 を比較して次のよらな特異点があげられている6

1）発病年令が 続発性では平均59才，原発性 では平均40才である，PVから痛風発病までの経 過年数は $1 \sim 4$ 年が多く, 平均 7 年である. 
2）性別は続発性が原疾患に性差が著明でない ので，男女ともに䍜患するが（女子約 $17 \%$ ),原発 性では男子が圧倒的に多く, 男:女比はほぼ20： 1 である。

3）家族的遺伝的発生は，続発性になく，原発 性にはかなり認められる。

4）血清尿酸值は，続発珄では平均 $12 \mathrm{mg} / \mathrm{dl}$ と高 值で, 原発性では平均 $9.1 \mathrm{mg} / \mathrm{d} 1$ 程度である。

5）関節炎については，前者では不規則な罹患 部位を有するが，後者では四肢末端ことに第 1 中 足趾関節を好発部位とし，完全緩解を有する定型 的急性関節炎発作である。

6）尿中尿酸排泄量は，前者では一様に多く， 尿酸による尿路結石症の合併も約 $40 \%$ と頻発する が，後者では多様で，結石頻度も約 $11 \%$ と少な w.

P Vは，血管障害，心障害，感染などの合併お よび白血病や再生不良性貧血八の転化などにより 予後を不良とするものが多い原発性痛風では腎 障害から尿毒症死，および脳血管障害，心死など が多く認められる．PVに痛風が合併したものの 経過和よび予後については詳らかにされていない が，その経過は多様であり，薬物による治療効果 は，原疾患の重症度，選択薬物により異なるもの である. Lawrenceは21例中 5 例に白血病死をみて お゙り ${ }^{12)}$ : Damonらは11例中 2 例が急性白血病に，

1 例が慢性白血病に発展するのをみている ${ }^{18)}$

赤血球増加症と高尿酸血症ないし痛風との関 係：PVに合併する続発性痛風の病態生理につ いての研究はいまだ不充分で，若干の文献がある にとどまつている.Yüは, glycine-15Nを用いて尿 酸生成機構を，PVと原発性痛風と比較研究して

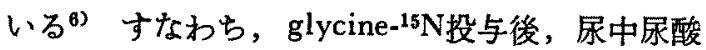
中に出現する尿酸-15Nの含有率をみると，原発性 痛風では 2 日目にはやくる高最值に達し, glycine よりの “shunt pathway”による直接的尿酸合成 の増加が推定される．PVないしPVK二次性痛 風を合併せる症例における尿中尿酸 ${ }^{15}$-Nの含有率 は，はじめの数日間正常者より低率であるが，15
日目に最高に達し，その後漸減する。尿酸 ${ }^{15}-\mathrm{N} の$ 総排泄量でみると，PVでは原発性痛風はどでは ないが，尿酸の過剩生成が認められた.すなわち， P Vの場合，骨髄造血能九進の一端として，glycineは 細胞内核酸の過鄱生成を介乙て，尿酸の過 剩生成をもたらするのと推定してょいであろう.

乙かし，PVと高尿酸血症または続発性痛風之 は常に合併するとは限らず，PVで正常血清尿酸 值を示すものがある理由は明確ではない。また骨 䯣造血機能六進が，細胞内核酸の過剩生成をるた らすとしても，血液三有形成分すなわち赤血球 系，白血球系，血小板系のい寸゙れの系の核酸の “ turn-over”の增加が尿酸過生産に関与するのか は明らかにされていない.Stroebelらは未熟な白血 球が高尿酸血症と関係ありとし ${ }^{10)}$ ，Hicklingは骨 髄和よび脾に和ける巨核球の過剰増殖が高尿酸血 症と相関ありとした ${ }^{17)}$. Denmanは最近99例のP Vについて，種々の血液検查項目と高尿酸血症と の関係について検討している8)そそれによると， 骨䯣線維症を有する P V 8 例の血清尿酸值は11.0 $\mathrm{mg} / \mathrm{dl}$ で, 全例平均の $6.1 \mathrm{mg} / \mathrm{dl}$ よりも有意に高值を 示した。また尿酸クリアランスの正常值下限を 5 $\mathrm{ml} / \mathrm{min}$ とて，52例中の50\%が正常，50\%が低下 を示して括り、クリアランス低下群は正常群より 血清尿酸值が高值を示した，尿酸クリアランス正 常群ではHt と血清尿酸值とが有意正相関を示し たが，尿酸クリアランス低下群ではそのような関 係が認められなかつた。またクリアランス正常群 の ${ }^{32} \mathrm{P}$ 治療による血清尿酸値の低下度と, $\mathrm{Ht}$ とも 有意正相関を示した. 全例99例中 8 例の痛風は， 全例尿酸クリアランス $5 \mathrm{ml} / \mathrm{min}$ 以下の低下群に 含まれていたという

以上の 3 報告は，高尿酸血症に関与する因子と して白血球系，栓球系，赤血球系のそれぞれ一系 たけをあげて特り，相互に排反するよらにみえ る、しかしLajtha沉れば，PVや慢性白血病は 骨䯣の最も未分化な“stem cell”自体の良性増殖 であるといら ${ }^{18)}$ 。この考えによれば， stem cell は血液三有形成分の分化以前のものであるから， 
上述の 3 報告は必ずしも誴りとはいえないが，同 時に真の解明にもなつていないといえよう

ヒト腎の疛酸排泄能は，尿細管による尿酸の生 理的再吸收機構の存在によりいちじるしい制約を らけているので, 尿酸過生産がおきても尿酸排泄 增加は不充分となり, 過尿酸血症から痛風発症に いたるるのと推定される。

われわれの P V に続発せる痛風症の 2 症例は， いずれる血清尿酸值が約 $11 \mathrm{mg} / \mathrm{dl}$ である、尿酸排泄 低下型の本邦人原発性痛風患者の 1 日平均尿酸排 泄量は 400mg以下と推定されるが19)。この 2 例の 尿中尿酸排泄量は $915 \mathrm{mg} / \mathrm{day}, 726 \mathrm{mg} / \mathrm{day}$ で, 約 2 倍に達している。これらは尿酸の過生産と， 過剩排泄とを示しているといえよう 尿酸クリア ランスはほぼ正常である。既述のように，われわ れの症候性赤血球增加症を含めた全 7 例中 5 例ま でが高㽷酸血症を示している。また 4 例が痛風を 合併している．これは，赤血球増加症ことに $\mathrm{P} \mathrm{V}$ の検索にあたつて，尿酸代謝検討の必要性を示唆 していると考える。

P V K続発する痛風症の発生機序は次のように 要約されよ5 PVには骨檤造血機能の亢進があ り, shunt pathwayによらない正常経路による尿 酸の過生産が和きる。この際就々らく核酸の過生 成と，そのturn-overの増加が介在するるのと推 定される、七ト腎の限られた尿酸処理能のため， 尿酸過生成は高尿酸血症をもたらす 高尿酸血症 Kよる尿酸処理増加の要求は腎障害を促がし，腎 障害は尿酸クリアランス低下の原因となり，悪循 環が成立する，かくしてPVに拈ける高尿酸血症 が痛風を続発せしめるものと考えられる。したが つてPVK战ける痛風む，尿酸のoverproduction と, under-excretion との 2 要素が関与するむの で, 結果的には原発性痛風と似た発生機序といえ
る、しかし P V や慢性白血病などblood dyscrasia の続発性痛風には，上述の 2 要素の両者が必要で あると考えられるに反し，原発性痛風では 1 要素 のみでも痛風が成立しらるとみなされている。

\section{結 語}

真性赤血球増加症に続発せる痛風の 1 症例につ き，6年間にわたり経過観察したので報告した。 また赤血球増加症について, 尿酸代謝の面に重点 を和いて自験 7 症例の臨床をのべるとともに，興 味ある所見について考察を加えた。

\section{文献}

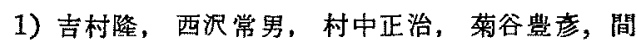
得之：リウマチ，3:299，1962. - -2）大島良雄, 吉村隆, 西沢常男 内科, 9:870, 1962. 一 - 3) Damon, A., Holub, D. A., Melicow, M. D. \& Uson, A.C.: Amer. J. Med., 25 : 182, 1958. 4) Talbott, J. H.: Gout, New York/London, Grune \& Stratton. 1967. - 5) Gutman, A. B.: Ann. Intern. Med., $39: 1062,1953$. - 6) Yü, T.F.: Arth. \& Rheum., 8: 765, 1965. - 7) Denman, A.M., Szur, L. \& Ansell, B.M.: Ann. rheum. Dis.. 23 : 139, 1964, -8) Denman, A.M., Szur, L. \& Ansell, B.M.: Ann. rheum. Dis., 25: 340, 1966. - 9) Kinell, L.J. \& Haden, R.L.: Med. Clin. N. Amer., 24:429, 1940. - 10) Stroebel, C.F., Hall, B.E. \& Pease, G.L.: J. Amer. med. Ass., $146: 1301,1951 . \quad-11$ ) Videbeck, A.: Acta med. Scand. $138: 179,1950$. -12) Lawrence, J. H., Berlin, N. I. \& Huff, R.C.: Medicine, 32 : 323, 1953. - 13) Damon, A., Holub, D.A.: Ann. Intern. Med., 49 : 43, 1958. 一14) 日比野進, 山崎僬之: 臨床血液, 2： 195, 1961. -15) Somerville, J.: Brit. Heart J., $23: 31,1961$. -16) Lewis, J.G.: Brit. Med. J., $1: 24,1961$. -17) Hickling, R.A.. Lancet, 1 : 175, 1958. -18) Lajtha, L. G. \& Oliver, R.: Ciba Found. Sym. Hemopoiesis, Wolstenholme, G.E.W. \& O'connor, M. Eds. pp. 289, 1960 . 19）赤岡家雄：リウマチ. $6: 322,1966$. 